\title{
Political culture and the changing role of countesses, $750-1050{ }^{1}$
}

Rachel Stone

In the early twelfth century, Donizo, an Italian monk, wrote a life of Countess Matilda of Canossa. ${ }^{2}$ He began by celebrating Matilda’s ancestors, including an account of how after the death of Matilda’s father Boniface in 1052, her mother Beatrice ruled the march of Tuscany:

Who can narrate how prudently his [Boniface’s] wife held honours after his end, living twice ten years and five completed after him.

Towns, castles, the march and her own land

Countess Beatrice held, governed rightly. ${ }^{3}$

To Donizo, Beatrice’s status as a countess and her ability to rule a territory independently as a widow needed no particular justification. Contemporary documents reveal more of Beatrice’s government, including her presiding over placita (judicial proceedings). ${ }^{4}$ Yet three centuries before a woman like Beatrice would not been called 'countess', nor would she have been found governing a county or march. This article will explore how the changing political culture of Carolingian and post-Carolingian Europe allowed countesses and duchesses new opportunities for rule.

Let us start by considering what is meant by 'political culture'. Gabriel Almond, who first coined the term, was a sociologist, working in the tradition of Max Weber and Talcott Parsons. Almond defined political culture as the 'particular pattern of orientations to political action' in a political system, ${ }^{5}$ and explained the three components of this: 
the first is perception, or cognition; the second is preference, involvement, or affect (cathexis); the third is evaluation or choice through the application of standards or values to the cognitive and affective components. By cognition is meant the knowledge and discrimination of the objects, events, actions, issues, and the like. By cathexis is meant the investment of objects, issues, etc., with emotional significance, or affect. By evaluation is meant the manner in which individuals organize and select their perceptions, preferences, and values in the process of establishing a position visà-vis political action. ${ }^{6}$

Although Almond was working within a Weberian understanding of political systems in which the state is seen as holding a monopoly of legitimate violence, he believed that the same methods could be used to study politics in 'simpler societies'. ${ }^{7}$ He also saw political action as key, arguing that research on political systems needed to focus on 'empirically observable behavior'; simply looking at legal or ethical norms was insufficient. ${ }^{8}$ Political culture, therefore, rather than focusing on the traditional hard nuts and bolts of political systems, like constitutions and institutions, investigates the more intangible 'squidgy bits' in between, the ideas and practices that keep the system moving. I want to use Almond's concept of political culture to think about the actions of one particular type of medieval political actor: aristocratic women.

Scholars' views of such women have changed substantially over the last thirty years. Amy Livingstone has critiqued the traditional historiography, in which any medieval women who exercised power was regarded as exceptional. As she points out, before 1990 it was rarely acknowledged that 'it was common and accepted for aristocratic women to hold courts, 
resolve disputes, mete out punishments, make proclamations, have clients, be patrons, command men, or hold office'.,9

In contrast, more recent studies of politics in the central Middle Ages have repeatedly demonstrated aristocratic women wielding power in these ways. ${ }^{10}$ Kimberley LoPrete talks of 'lordly women', women who acted in the same way as any male lord. ${ }^{11}$ Yet the focus of recent research has been on the eleventh and twelfth centuries, especially in France. I want to go further and ask when such wielding of power by aristocratic women first appeared in western Europe.

\section{Carolingian comital women}

This article will look at countesses (and duchesses) in the Carolingian empire and the polities succeeding it (France, Germany, Italy, the Low Countries and Catalonia). ${ }^{12}$ However, this immediately raises the problem of identifying countesses. ${ }^{13}$ The word 'comitissa' first appears in authentic documents in 865 and only becomes common in the tenth century. ${ }^{14} \mathrm{I}$ will therefore begin by looking at the activities of the wives, widows and daughters of Carolingian counts up to around 887. I will refer to these women as comital women, as an analogy with Kimberley LoPrete’s ‘lordly women’.

A complete analysis of such women is impossible; there are thousands of surviving eighth and ninth-century charters, many referring to counts and their relatives. ${ }^{15}$ Yet the main reference tools for Carolingian counts are revealing: a number of prosopographies of Carolingian officeholders exist, but these say little about the wives and daughters of these men. ${ }^{16}$ This is not due to any bias by the compilers; in many cases our sources give us few details about these women. 
Those Carolingian comital women about whom we are informed have a variety of roles that are political in the widest sense, as five examples from different regions show. The first comes from 764, when Willeswind and her son, Count Cancor, founded the monastery of Lorsch in the Rhineland and gave it to their relative, Bishop Chrodegang of Metz. Matthew Innes argues that it may have been Willeswind's backing that was the determining factor in the monastery's success. ${ }^{17}$ Indeed, the foundation charter of Lorsch is in her name, donating land she inherited from her father, Count Adelhelm. Willeswind's family were connected to the dukes of Thuringia, as reflected in Cancor's brother being called Turincbert. ${ }^{18}$ Another female relative had previously co-founded a monastery in Mainz. ${ }^{19}$

Women like Willeswind are familiar political actors in Francia from the seventh century onwards: inheritors of property, whose marriages connected together noble families, and who used monasteries to solidify and protect their family power and memory. We can see a similar woman in the late ninth-century Vita Liutbirgae. Gisla was the daughter of Hessi, a Saxon count and married to another count, Unwan. She founded two monasteries and placed one of her daughters over each one; she also carried out other good works, including the building of churches. ${ }^{20}$ Gisla continued to manage her property as a widow; it was during one of these trips that she met the young Liutbirga in a convent and persuaded her to come and live with her. ${ }^{21}$ On her deathbed, Gisla not only explained to her son Bernhard how great an inheritance she was leaving him, but 'demanded' of him that he would protect his sisters and Liutbirga and take Liutbirga’s advice. ${ }^{22}$ Gisla shows us an active comital woman, managing her family's resources and well able to get what she wanted.

Another tiny vignette comes from the chronicler Regino from 881: during a Frankish siege of a Viking troop camped in the royal palace of Nijmegen, 'Eberhard Saxo, son of 
Count Meginhard, was caught by the enemy and taken prisoner; his mother Evesa later got him back unharmed by paying a large sum. ${ }^{\text {23 }}$ By 885 Eberhard was a count in Frisia himself; ${ }^{24}$ unfortunately, we know no more about the activities of the redoubtable Evesa. ${ }^{25}$ She clearly, however, was not only wealthy, but able to command and direct the use of this wealth herself.

A fourth example of a political woman who was both the wife and the daughter of a count is Engeltrude, the daughter of Count Matfrid of Orléans and the wife of an Italian count called Boso. ${ }^{26}$ At first sight, Engeltrude’s actions in running away with her lover, Wanger, a vassal of Bodo, might seem personal, rather than public. Yet this marital dispute became an immensely public one: Engeltrude gained support from King Lothar II of Lotharingia and some of his churchmen, while Boso sought help from successive popes and had the matter discussed at several Frankish councils. Engeltrude never returned to her husband and probably managed to pass on some of her property to her bastard son. ${ }^{27}$ She shows us a comital woman able to manoeuvre successfully between multiple sources of power.

Finally, there is Dhuoda, the wife of Bernard, Count of Septimania, famous for the handbook she wrote for her teenage son William. ${ }^{28}$ As Janet Nelson and Régine Le Jan have shown, this handbook is not simply the 'private' work of a mother. Dhuoda had been a courtier and she wrote as someone who knew how to win friends and influence people. Her intended audience was not only William himself, but probably also William’s contemporaries at court, including Charles the Bald. ${ }^{29}$

Carolingian sources thus show us a number of politically powerful comital women; yet there are also noteworthy gaps in their activities related to the specific military, 
administrative and judicial roles of Carolingian counts. ${ }^{30}$ Firstly, with one possible exception, I have not so far found such women participating in or leading warfare. ${ }^{31}$ Indeed one capitulary, instructing Carolingian counts in raising the host, specifically assumes that their wives would not take part: the count must take his men with him, but is allowed to leave two of his 'housed men’ with his wife. ${ }^{32}$ Secondly, although royal women and abbesses are sometimes mentioned as having their own armed followers (vassi, fideles, homines), nonroyal laywomen are not shown as holding such men. ${ }^{33}$

Thirdly, there is no evidence of non-royal women presiding over court judgements before the year 900, although a handful of queens and empresses did so. ${ }^{34}$ The negative evidence we get from Dhuoda is also interesting. She describes herself as carrying out 'service’ to Bernard in the Spanish March during his absence ${ }^{35}$ but says very little specifically to William about how to be a judge, a topic discussed in some detail by other Carolingian writers of lay mirrors. ${ }^{36}$ Finally, comital women are not shown acting as regents for underage sons. In fact, sometimes the sources explicitly state that rulers redistributed a dead count's honores to men other than his relatives. ${ }^{37}$

Carolingian women, therefore, were probably excluded from some activities particularly associated with counts and dukes. In addition, what we can observe of such women's family consciousness is often not specifically linked to comital offices, as seen for example, in the changing references to Willeswind in Lorsch sources. In the chronicle part of the Codex Laureshamensis, written around 1170, Willeswind is called a religiouslyconsecrated woman, the mother of Cancor, the 'illustrious count of the Rhinegau', and the widow of Count Rupert. ${ }^{38}$ In the text of the original charter within the chronicle, however, Willeswind does not refer to Rupert, but describes the donation as made by 'I, Willeswind, 
consecrated to God and my son Count Cancor', for the remedy of their souls. ${ }^{39}$ Indeed, there is no reference to Rupert in any of the charters mentioning Willeswind. ${ }^{40}$ Willeswind states that the villa of Hagenheim she is donating came to her 'by law, from the share of my father, Adelhelm by name', but there is no mention of Adelhelm having been a count. ${ }^{41}$

Eight years later, in 772, after the deaths of Willeswind and Cancor, a dispute between Cancor's son Heimeric and Lorsch was brought before Charlemagne. The abbot of Lorsch explained how the 'grandmother of this Heimeric, Willeswind by name, and his father Cancor' had transferred the monastery to the 'lord Archbishop Chrodegang' ${ }^{42}$ Here again, comital titles have disappeared and the memory of the family is sharply limited.

It is also worth looking at Dhuoda’s Liber manualis, whose memorialisation of William's family has often been stressed. ${ }^{43}$ Dhuoda urges William to pray for Theoderic, his godfather, probably William’s paternal uncle and the count of Autun; Dhuoda herself describes him only as 'the lord Theoderic'. ${ }^{44}$ When she tells William about other relatives for whom he is to pray, she gives only a list of names. ${ }^{45}$ This is despite the fact that some of those listed previously held high office, such as Bernard's father, Count William of Toulouse. Dhuoda wants William to pray for those of his father's relatives who have left him property, but their previous titles appear irrelevant. ${ }^{46}$

\section{Tenth-century countesses}

It is instructive to compare Carolingian comital women with countesses in tenth and eleventh-century Spain and southern France. Such women are often specifically called countesses: the title is first documented for Berteiz, the widow of a Count of Toulouse in 865 and is regularly used in Catalonia after $885 .{ }^{47}$ These countesses continued to carry out 
traditional female political activities, such as donating to and managing monasteries. ${ }^{48}$ In addition, however, they also performed new activities, such as acting as regents for underage sons. Countess Ava of Cerdagne-Besalú, for example, was widowed in 927. In 941 she was still being called countess and making donations at the head of her three sons, Wifred, Oliba and Miro, two of whom were by now counts themselves. ${ }^{49}$

These comital women now also presided over judicial assemblies, as Jeffrey Bowman has discussed. His earliest example is from 927, where Countess Ilduara Eriz (Aldara de Celenova), her husband Gutierre Menéndez and her son presided over a dispute. ${ }^{50}$ Around the year 1000, Countess Ermessenda of Barcelona repeatedly presided over such assemblies. ${ }^{51}$ Slightly further north, Agnes, duchess of Aquitaine, convened a placitum in $1044 .{ }^{52}$ Such countesses might also have their own men: for example, the record of an oath survives from the 1040s in which a certain Amat swears fidelity to Countess Elisabeth, the wife of Ramon Berenguer I of Barcelona. ${ }^{53}$ Countess Ermessenda took part in military campaigns against alAndalus. ${ }^{54}$

As well as completely new kinds of activity, such as making conventiae (sworn agreements) and holding castles, ${ }^{55}$ comital women were thus carrying out political activities that appear in the Carolingian sources only as performed by men. The obvious question is whether this difference represents changing documentation, regional differences in women's activities or a genuine political change.

It is unlikely that the difference is purely due to changes in documentary practice. Several hundred eighth and ninth century placita survive, so we could expect to see some comital women as judges, if their numbers were comparable to lordly women's presence in 
eleventh century records. ${ }^{56}$ Similarly, we could expect to see at least some Carolingian sources showing comital women acting as regents.

The question of a possible regional difference is more complicated, especially when using Spanish evidence. There are fewer than a hundred charters from Catalonia before 850 and thousands from the tenth century; ${ }^{57}$ in contrast, some of the great Carolingian centres of charter production, such as Fulda, have a sharp drop in documents in the tenth century. ${ }^{58}$

Nevertheless, there is evidence of change beyond Spain and Mediterranean France. The term 'comitissa' appears in late ninth-century and early tenth-century texts in a number of different regions, including in necrologies from Gorze, Verdun, Auxerre, Paris, Rheims and Fulda. ${ }^{59}$ It is also possible to see new roles for comital women in other regions in the tenth and early eleventh century.

In northern Italy, by around 1050 a countess like Beatrice of Canossa could rule a territory and there are earlier examples of women carrying out comital functions. In the cathedral of Lucca, an inscription commemorates Bertha of Tuscany, who died in 926, as a countess. ${ }^{60}$ Bertha has a wider political role than earlier comital women, including writing to the Caliph in Baghdad. ${ }^{61}$ (None of the few letters by or from comital women from the Carolingian period carry out international diplomacy). ${ }^{62}$ Liudprand of Cremona’s hostile account of Bertha describes her not only as an malign influence on her husband Adalbert II, margrave of Tuscany, but as retaining her political role after his death in 915 and able to control a number of castles. ${ }^{63}$ 
Meanwhile, Bertha’s daughter, Ermengard, the wife of Adalbert I, margrave of Ivrea, is shown as having vassi in a judgement from 927, while a charter from 924 describes her (along with Boniface of Spoleto) as royal consiliarii. ${ }^{64}$ Liutprand claims that after Adalbert's death Ermengard had 'primacy in all Italy' ${ }^{65}$ Nor was Ermengard the only comital woman in tenth century Italy with her own vassi. ${ }^{66}$

There is parallel evidence for comital and ducal women in the Ottonian and Salian empires. After the death of Duke Henry I of Bavaria in 955, his widow Judith acted as regent for her underage son, Henry II (the 'Quarrelsome'). ${ }^{67}$ Similarly, in the late tenth century, Beatrice, the widow of Duke Frederic I of Upper Lorraine, acted as regent for her young son, as well as playing a leading role in diplomacy between the Ottonians and French rulers. ${ }^{68}$ In the late tenth century, Judith's daughter Hadwig, the widowed duchess of Swabia is described as holding a ‘colloquium publicum' and some royal charters refer to her as 'dux'. 69

From the tenth century, comital women also sometimes carried out military roles. A letter from Gerbert of Aurillac in 985 urges Matilda, wife of the captive Godfrey I, Count of Verdun to continue to defend the couple's castles rather than making a peace treaty with the French. ${ }^{70}$ Adele of Hamaland married Count Balderic of Drenthe and was accused of the murder of the Saxon count Wichman Billung III in 1016. According to one account, she continued to defend the castle of Upladen when it was attacked in revenge for Wichman's death, even after her husband surrendered. ${ }^{71}$

\section{Noblewomen and power}

What we can see in the sources, I would argue, is an expanded range of possible actions for comital women in the tenth and eleventh centuries as well as a new representation 
of them as countesses and the descendants of counts. How does this fit with the existing historiography of medieval women's power? One of the main paradigms is still that suggested by Jo Ann McNamara and Suzanne Wemple in a classic article from $1973 .{ }^{72}$ This contrasts an early medieval period seen as marked by no distinction between 'public' and 'private' power, in which women could exercise many forms of power through family connections, with an eleventh and twelfth century in which the reconstitution of some of the institutions of public power led to the exclusion of women from power. ${ }^{73}$ McNamara later claimed that the entire gender system destabilized in the late eleventh century, with powerful women being replaced by 'ungendered' men in public life. ${ }^{74}$ Yet this idea of a decline in the power of noblewomen and queens after 1100 has increasingly been called into question by historians. ${ }^{75}$ A number of researchers have also demonstrated that thinkers in the Carolingian period did have a clear concept of a public sphere. ${ }^{76}$

Another long-lasting paradigm of women's opportunities in the period before the year 1000 was provided by Suzanne Wemple’s Women in Frankish Society. Wemple contrasted the 'decentralized' societies of the Merovingian and post-Carolingian periods, in which women were active in political and cultural life with a Carolingian world in which 'women of the aristocracy faced a decline in the number of social opportunities available to them. ${ }^{, 77}$

However Wemple's contrast is hard to sustain for lay noblewomen. The evidence from the Merovingian period for specifically comital women is fragmentary, but does not suggest that such women were more politically active than they were under the Carolingians. ${ }^{78}$ The appearance of new activities by comital women in a variety of different post-Carolingian polities, from the Ottonian empire to more-or-less independent Catalan counties also makes ‘political decentralization’ unlikely to be the key factor. 
A more useful analysis comes from Régine Le Jan, who first pointed out the significance of the appearance of the term comitissa in the late ninth and early tenth century, as one of several changes in the ideology surrounding the count's wife. ${ }^{79}$ She saw this change as inspired by Carolingian churchmen's model of conjugality, which stressed marriage as a moral, emotional and material community, and made the marital bond into a true consortium. ${ }^{80}$ Le Jan also argued for a practical change coming from this new status, with comital wives more able to participate in the management of the couple's goods, as reflected in the increased appearance of wives' consent to their husband's donations. ${ }^{81}$

Le Jan suggests several ideological and political reasons for a wider acceptance of this conjugal model in the late ninth century. She first mentions the influence that developing practices of Carolingian queenship had on the idea of a countess. As she points out the term comitissa itself is inspired by the parallelism of rex/regina. ${ }^{82}$ Ninth century changes in Frankish ideology concerning the king's wife have often been discussed; ${ }^{83}$ indeed, Janet Nelson sees changes already with Bertrada, the first Carolingian queen in the mid-eighth century. ${ }^{84}$ Le Jan also links the appearance of 'comitissa' with the use by counts of formulae such as 'ego gratia Dei comes', although there are considerably earlier examples of this phrase. ${ }^{85}$

As well as these ideological changes, Le Jan also sees wider changes in family structure. These include the marriages of the elite becoming more homogamous, with both spouses equally noble. ${ }^{86}$ And from the 880 s, Le Jan sees an increasing move among many noble families to organise their lineages around the direct transmission of particular offices. ${ }^{87}$ 
Some of Le Jan's suggested factors for the changing position of comital women look more plausible than others. An emphasis on conjugality and the conjugal couple as the basic unit of society has now been traced back to Roman times. ${ }^{88}$ Moreover, an ideology of conjugality is entirely compatible with notions of 'separate spheres', in which women can be excluded from official political roles, even while providing extensive political support and advice behind the scenes. Overall, it seems unlikely that lay acceptance of the Carolingian ideology of marriage in itself would have allowed political opportunities for comital women in early tenth century Catalonia and Italy that had not been available for Dhuoda in the 840s.

In addition, while the model of Carolingian queenship was important for countesses, the differences should also be noted. As the term 'queenship' itself suggests, Carolingian queens had an official and institutional position within the kingdom. They were mentioned in capitularies and political tracts and might be ceremonially consecrated or crowned. ${ }^{89}$ In contrast, I am aware of no early rituals, laws or political theories that deal with the role of the countess.

It is also hard to be sure how much homogamy in terms of status did increase in the tenth century. Merovingian sources already often stress the 'nobility' of both spouses in a couple. ${ }^{90}$ Since our principal eighth and ninth-century sources for the wives of counts (charters and necrologies) infrequently mention their fathers, it is difficult to be certain of their social status, although their names often suggest membership of elite families. In contrast, from the tenth century onwards, it is increasingly possible to be more specific about the origins of such women. ${ }^{91}$ In other words, it may be that a new textual emphasis on mentioning comital lineages simply reveals already existing high levels of homogamy. 
Le Jan's point about the new organisation of lineages around the direct transmission of particular offices seems to me the key factor. Her vision of this is not the simple contrast developed by Karl Schmid and Georges Duby between the supposedly large, diffuse and undifferentiated structures of kinship characteristic of the early Middle Ages and more tightly-defined patrilineages visible in the central Middle Ages. ${ }^{92}$ Le Jan instead argues for a model of post-Carolingian families marked by a regional focus, mobilising all family members to reinforce a central area of control and expand it. ${ }^{93}$ (This contrasts with a Carolingian situation where wide and interlocking kinship ties allowed highly-placed individuals more freedom to choose a particular side in a conflict and/or relocate to gain honores. $)^{94}$

Studies of family consciousness confirm such changes. Constance Bouchard argues that the model of a patrilineal family, stressing male line descent, was first created by the Carolingian court in the late eighth century and gradually taken up by the highest aristocracy during the ninth and tenth century. ${ }^{95}$ Although such a patrilineal model focused on men, it left room to recall the illustrious background of the wives who married into the lineage. In 936, for example, Richildis, viscountess of Narbonne, described herself in a charter as 'Richildis, viscountess, daughter of Count Borell and daughter of the deceased countess Garsinda. ${ }^{96} \mathrm{~A}$ charter from Piacenza in 1002 records a donation by 'Count Lanfranc son of the deceased Riprand, also count and his wife Berta, daughter of the marchio of good memory Adalbert. ${ }^{97}$ Both statements seem to me a long way from the self-descriptions of Willeswind or Dhuoda.

We also have evidence of a tenth-century change in how counties were acquired and transmitted. Although Dhuoda was noble and her husband Bernard held high office, her hope for William is that he might please Charles the Bald enough to gain honores. ${ }^{98}$ Throughout 
the Carolingian period we see preferential access by members of a few families to comital office rather than direct inheritance. ${ }^{99}$ Such a pattern was encouraged by the influential courtier and moralist, Archbishop Hincmar of Rheims, who in 882 wrote a treatise on government, De ordine palatii. Advising the young king Carloman on how to restore palace institutions, Hincmar says:

I know no-one to be now alive from those who were seen at the time of the lord emperor Louis [the Pious] as palace administrators and governors of the kingdom. Yet I know that sons were born from their nobility for the benefit of their fathers, although I do not know their character and qualities...To the extent of their merit, let them fill the places and offices of their fathers. ${ }^{100}$

Father-son holding of office is envisioned here, but mediated through the king's choice of a worthy successor. In contrast, in 990, Adelaide, the widowed viscountess of Narbonne, explicitly bequeathed the viscounty to her son. ${ }^{101}$ Office here is seen as personal property, rather than coming from royal appointment. The corollary of that was that there was no obvious reason while such personal property could not be inherited and held by women.

\section{Conclusion}

The changed position of countesses in the tenth and eleventh century was not an automatic consequence of political fragmentation or ‘decentralization’. Nor was it due to new institutional structures of ‘countess-ship’ or laws. Instead, we see a changed political culture in Almond's sense of a 'particular pattern of orientations to political action'. Cognition, cathexis and evaluation were bound up together to produce new opportunities for comital women's political actions. In terms of cognition, the wives of counts were categorised 
differently by 1000 (as seen in the new term comitissa); the investment of emotion in such women's comital status is seen both in their own charters and the writings of an author such as Liutprand. Finally, such perceptions and feelings were combined with a new understanding of office-holding, leading to a re-evaluation of countesses as fit persons to carry out particular political roles, as seen in Donizo’s description of Beatrice. I would argue that such re-evaluations by contemporaries were crucial for countesses' ability to carry out new activities. After all, a countess (like any male holder of an honor) could only act as a regent, preside over a dispute or organise military action if her authority was accepted by those around her and her orders and decisions regularly adhered to.

All this suggests that we may need to revise further our existing models of changes in medieval noblewomen's power. It also shows the usefulness of 'political culture' in exploring political change, as an alternative to a focus either on individuals and political factions or on structural changes to laws and institutions. It encourages us to look for 'patterns of orientation' and thus broaden our view beyond supposedly ‘exceptional’ personalities. A political culture approach, with its focus on 'politics in action', allows us to explore more fully not only well-documented societies, but also periods and places, such as tenth century Western Europe, which have few sources of legal evidence or political theory. By studying the changing meanings and emotions attached to particularly political institutions, it can also help us understand how concepts such as 'countess' (or 'sovereignty') can abruptly take on new and charged political significance. A full understanding of politics, as has become apparent in 2017, requires a deep engagement both with the political culture and with the wider social culture in which it is embedded. 
${ }^{\mathbf{1}}$ I wish to thank Katy Dutton for inviting me to speak at the conference and Julie Hofmann, Fraser McNair, François Bougard and Charles West for advice on the article and providing additional examples of comital women.

2 Donizone di Canossa, Vita Mathildis, celeberrimae principis Italiae, ed. Luigi Simeoni, Rerum Italicarum Scriptores (ser. II), 5, 2 (Bologna, 1930-40).

${ }^{3}$ Ibid., pp. 44-5, v. 1138-42:

'Quis narrare potest quantum prudenter honores

Eius post finem tenuit coniunx sua, vivens

Bis denis annis post ipsum quinque peractis?

Oppida, castella, marcham, propriam quoque terram,

Rite gubernavit, tenuit comitissa Beatrix.’

${ }^{4}$ On Beatrice, see Elke Goez, Beatrix von Canossa und Tuszien: eine Untersuchung zur

Geschichte des 11. Jahrhunderts (Sigmaringen, 1995), especially pp. 72-99.

${ }^{5}$ Gabriel A. Almond, ‘Comparative political systems’, Journal of Politics 18 (1956), pp. 391409 at p. 396.

${ }^{6}$ Ibid.

${ }^{7}$ Ibid., p. 394.

${ }^{8}$ Ibid., p. 393.

${ }^{9}$ Amy Livingstone, 'Recalculating the equation: powerful woman = extraordinary', Medieval Feminist Forum 51, no. 2 (2015), pp. 17-29 at p. 17.

${ }^{10}$ See e.g. Theodore Evergates, (ed.), Aristocratic Women in Medieval France (Philadelphia, 1999); Fredric L. Cheyette, Ermengard of Narbonne and the World of the Troubadours (Ithaca, 2001); Kimberly A. LoPrete, Adela of Blois: Countess and Lord (c.1067-1137) (Dublin, 2007); Amy Livingstone, Out of Love for my Kin: Aristocratic Family Life in the Lands of the Loire, 1000-1200 (Ithaca, 2010). 
${ }^{11}$ Kimberly LoPrete, 'The gender of lordly women: the case of Adela of Blois', in Christine Meek and Catherine Lawless (eds), Studies on Medieval and Early Modern Women: Pawns or Players? (Dublin, 2003), pp. 90-110.

${ }^{12}$ On Carolingian noblewomen generally see Suzanne Fonay Wemple, Women in Frankish Society: Marriage and the Cloister, 500 to 900 (Philadelphia, 1981); Hans-Werner Goetz, Frauen in frühen Mittelalter. Frauenbild und Frauenleben im Frankenreich (Weimar, 1995); Valerie L. Garver, Women and Aristocratic Culture in the Carolingian World (Ithaca, 2009). ${ }^{13}$ The boundary between the titles of comes, marchio and $d u x$ was unclear until at least the tenth century: see Walther Kienast, Der Herzogstitel in Frankreich und Deutschland (9. bis 12. Jahrhundert) (Munich, 1968), p. 443.

${ }^{14}$ Régine Le Jan, 'L’épouse du comte du IXe au XIe siècle: transformation d'un modèle et idéologie du pouvoir', in Stéphane Lebecq, et al. (eds), Femmes et pouvoirs des femmes à Byzance et en Occident: (VIe-XIe siècles): colloque international organisé les 28, 29 et 30 mars 1996 à Bruxelles et Villeneuve d'Ascq (Villeneuve d'Ascq, 1999), pp. 65-73 at p. 69. On duchesses’ titles, see Kienast, Herzogstitel, pp. 341-2.

${ }^{15}$ Mark Mersiowsky, Die Urkunde in der Karolingerzeit: Originale, Urkundenpraxis und politische Kommunikation, Schriften der Monumenta Germaniae Historica, 60 (Wisebaden, 2015) I, pp. 291-412 provides a region-by-region analysis of Carolingian private charters. ${ }^{16}$ The main prosopographies I have used are Michael Borgolte, Die Grafen Alemanniens in merowingischer und karolingischer Zeit: eine Prosopographie (Sigmaringen, 1986); Philippe Depreux, Prosopographie de l'entourage de Louis le Pieux (781-840), Instrumenta, 1 (Sigmaringen, 1997); Sophie Glansdorff, Comites in regno Hludouici regis constituti: prosopographie des détenteurs d'offices séculiers en Francie orientale, de Louis le Germanique à Charles le Gros, 826-887, Instrumenta, 20 (Ostfildern, 2011); Eduard Hlawitschka, Franken, Alemannen, Bayern und Burgunder in Oberitalien (774-962): Zum 
Verständnis der fränkischen Königsherrschaft in Italien, Forschungen zur oberrheinischen Landesgeschichte, 8 (Freiburg im Breisgau, 1960); Régine Le Jan, ‘Prosopographica neustrica: Les agents du roi en Neustrie de 639 à 840', in Hartmut Atsma (ed.), La Neustrie: les pays au nord de la Loire de 650 à 850: colloque historique international, Beihefte der Francia, 16 (Sigmaringen, 1989), I, pp. 231-69.

${ }^{17}$ Matthew Innes, 'Kings, monks and patrons: political identity at the abbey of Lorsch', in Régine Le Jan (ed.), La royauté et les élites dans l'Europe carolingienne (début IXe siècle aux environs de 920) (Villeneuve d’Ascq, 1998), pp. 301-24 at p. 309.

${ }^{18}$ Ibid., p. 305.

${ }^{19}$ Régine Le Jan, Famille et pouvoir dans le monde franc (VIIe - Xe siècle): essai d'anthropologie sociale (Paris, 1995), p. 53.

${ }^{20}$ Ottokar Menzel (ed.), Das Leben der Liutbirg, MGH Deutsches Mittelalter 3 (Leipzig, 1937), c. 1-2, pp. 10-11.

${ }^{21}$ Ibid., c. 3, pp. 11-12.

22 Ibid., c. 7, p. 14-15.

${ }^{23}$ Regino of Prüm, Chronicon, ed. Friedrich Kurze, MGH SRG 50 (Hanover, 1890), s.a. 881, p. 117: 'In qua congressione captus est ab adversariis Everhardus Saxo, filius Meginardi comitis, et captivus ductus; quem postea mater Evesa magno pretio dato incolumem recepit.' ${ }^{24}$ Ibid., s.a. 885, p. 124. On Eberhard see Glansdorff, Comites, pp. 112-13.

${ }^{25}$ Evesa may appear in an entry in the Reichenau memorial book: see Johanna Maria van Winter, 'Die Hamaländer Grafen als Angehörige der Reichsaristokratie im 10. Jahrhundert', Rheinische Vierteljahrsblätter 44 (1980), pp. 16-46 at pp. 34-8.

${ }^{26}$ On Engeltrude see Rachel Stone, “'Bound from either side’: the limits of power in Carolingian marriage disputes, 840-870’, Gender and History 19 (2007), pp. 467-82; on Boso see Hlawitschka, Franken, pp. 158-62. 
${ }^{27}$ John VIII, Epistola 129, ed. Erich Caspar, MGH Epistolae VII (Berlin, 1928), p. 115 refers to estates held by the 'spurius Godefredus', a family name of the Matfrids (Le Jan, Famille et pouvoir, p. 444).

${ }^{28}$ Dhuoda, Handbook for her Warrior Son: Liber manualis, ed. and trans. Marcelle Thiébaux, (Cambridge, 1998).

${ }^{29}$ Janet L. Nelson, 'Dhuoda', in Patrick Wormald and Janet L. Nelson (eds), Lay Intellectuals in the Carolingian World (Cambridge, 2007), pp. 106-20; Régine Le Jan, ‘Dhuoda ou l’opportunité du discours féminin', in Christina La Rocca (ed.), Agire da donna: modelli e pratiche di rapprensentazione (secoli VI-X): atti del convegno (Padova, 18-19 febbraio 2005) (Turnhout, 2007), pp. 109-28.

${ }^{30}$ On the role of counts, see Karl Ferdinand Werner, 'Missio-marchio-comes. Entre l'administration centrale et l'administration locale de l'Empire carolingien', in Werner Paravicini and Karl Ferdinand Werner (eds), Histoire comparée de l'administration (IVe XVIIe siècles). Actes du XIVe colloque historique franco-allemand de l'Institut Historique Allemand de Paris (Munich, 1980), pp. 191-239; Matthew Innes, ‘Charlemagne’s government', in Joanna Story (ed.), Charlemagne: Empire and Society (Manchester, 2005), pp. 71-89.

${ }^{31}$ Hincmar of Rheims, De villa Novilliaco, c. 4, ed. Hubert Mordek, 'Ein exemplarischer Rechtsstreit: Hinkmar von Reims und das Landgut Neuilly-Saint-Front‘, Zeitschrift der Savigny-Stiftung für Rechtsgeschichte, Kanonistische Abteilung 83 (1997), pp. 86-112 at p. 104: 'Deinde Landrada, uxor Donati, sed et filii eorum, pergente Karolo rege ad obsidendos Nortmannos, qui in insula, quae Oscellus dicitur, residebant, cum aliis defecerunt.'

${ }^{32}$ Capitulare missorum de exercitu promovendo 808, in Alfred Boretius and Victor Krause (eds), Capitularia regum Francorum (Hanover, 1883-97), I, p. 137, no. 50, c. 4: ‘De 
hominibus comitum casatis isti sunt excipiendi et bannum rewadiare non iubeantur: duo qui dimissi fuerunt cum uxore illius.’

${ }^{33}$ The most detailed study of Carolingian vassi is Walther Kienast, Die fränkische Vasallität von den Hausmeiern bis zu Ludwig dem Kind und Karl dem Einfältigen (Frankfurt am Main, 1990), who does not mention any examples. He does find (p. 255) a few examples of women themselves being described as fideles (the earliest reference is from 877). On the vassi of princesses and abbesses, see Rachel Stone, Morality and Masculinity in the Carolingian Empire (Cambridge, 2012), p. 191.

${ }^{34}$ Cesare Manaresi, (ed.), I placiti del 'Regnum Italiae’, 3 vols., Fonti per la storia d’Italia, 92, 96 (bis), 97 (bis) (Rome, 1955-1960) I, pp. 277-83, no. 77 (Angilberga, 874); Maurice Prou and René Poupardin, (eds), Recueil des actes des rois de Provence (855-928) (Paris, 1920), pp. 49-51, no. 28, (Irmingard of Provence, 890); Janet L. Nelson, 'The siting of the Council at Frankfort: some reflections on family and politics’, in Rainer Berndt (ed.), Das Frankfurter Konzil von 794: Kristallisationspunkt karolingischer Kultur: Akten zweier Symposien (vom 23. bis 27. Februar und vom 13. bis 15. Oktober 1994) anlässlich der 1200Jahrfeier der Stadt Frankfurt am Main (Mainz, 1997), I, pp. 149-165 at p. 160 suggests Fastrada may have presided at a placitum.

${ }^{35}$ Dhuoda Liber manualis, 10, 4, p. 226: 'Pro utilitatibus domini et senioris mei Bernardi, ut meum erga illum, in Marchis vel in multis locis, non vilesceret servitium’.

${ }^{36}$ Ibid., 4, 8, p. 154: 'Dilige iustitiam, ut iustus esse vidaris in causis.' On other writers' advice, see Stone, Morality, pp. 164-7.

${ }^{37}$ Annales Bertiniani, ed. George Waitz, MGH SRG 5 (Hanover, 1883), s.a. 866, p. 84 (Robert the Strong); Annales Fuldenses, ed. Friedrich Kurze, MGH SRG 7 (Hanover, 1891), s.a. 884, p. 110 (William and Engelschalk). 
${ }^{38}$ Karl Glöckner, (ed.), Codex Laureshamensis, 3 vols. (Darmstadt, 1929-1936), I, p. 265, c.

1: 'Cancor illustris rhenensis pagi comes cum matre sua religiosa et deo acceptabili

Williswinda, uidua Ruperti comitis’.

${ }^{39}$ Ibid., I, p. 267, no. 1: ‘ego Williswinda deo sacrata et filius meus Cancor comes, pro dei intuitu uel pro animę nostrę remedio’.

${ }^{40}$ Ibid, I, p. 273, no. 3; I, p. 274, no. 4; II, p. 31, no. 228; II, p. 169, no. 598. Paul the Deacon, Gesta episcoporum Mettensium, ed. George Waitz, MGH Scriptores 10 (Hanover, 1852), p. 540, c. 37 refers to Lorsch as founded by 'Chillisuindis quondam religiosa femina et Cangro eius filius'.

${ }^{41}$ Codex Laureshamensis I, p. 267, no. 1.

${ }^{42}$ Ibid, I, p. 273, no. 3. Although the text of the placitum has been abridged, other comital titles are later mentioned; it is not obvious why they should have been removed from Cancor's name if present in the original.

${ }^{43}$ See e.g. Matthew Innes, 'Keeping it in the family: women and aristocratic memory, 7001200', in Elisabeth van Houts (ed.), Medieval Memories: Men, Women and the Past, 7001300 (Harlow, 2001), pp.17-35 at pp. 18-23; Constance Brittain Bouchard, 'Family structure and family consciousness among the aristocracy in the ninth to eleventh centuries', Francia 14 (1986), pp. 639-58 at pp. 641-4.

${ }^{44}$ Dhuoda, Liber manualis, 8, 15, p. 206.

45 Ibid., 10, 5, p. 226.

${ }^{46}$ Ibid., 8, 14, p. 204.

${ }^{47}$ Martin Aurell, Les noces du comte: mariage et pouvoir en Catalogne (785-1213) (Paris, 1995), pp. 151-2.

${ }^{48}$ Jeffrey A. Bowman, 'Countesses in court: elite women, creativity,and power in northern Iberia, 900-1200', Journal of Medieval Iberian Studies 6 (2014), pp. 54-70 at pp. 62-4 
${ }^{49}$ Aurell, Noces du comte, p. 153; other widowed Catalan countesses in the tenth-century also did so (p. 551). Thierry Stasser, 'La maison vicomtale de Narbonne aux Xe et XIe siècles', Annales du Midi 105 (1993), pp. 489-507 at p. 490 suggests Richildis, viscountess of Narbonne may also have acted as a regent in the late 920s.

${ }^{50}$ Bowman, 'Countesses in court' at p. 60. However, his reference (p. 61) to a 'Countess Dela' in the late ninth century is incorrect: the charters refer to Delà, count of Empúries. ${ }^{51}$ Ibid. at pp. 54-8.

${ }^{52}$ Emmanuelle Santinelli, Des femmes éplorées?: les veuves dans la société aristocratique du haut Moyen Âge (Villeneuve-d’Ascq, 2003), p. 373.

${ }^{53}$ Gaspar Feliu and Josep M. Salrach, (eds), Els pergamins de l'arxiu comtal de Barcelona de Ramon Borrell a Ramon Berenguer I (Barcelona, 1999), pp. 759-60, no. 384. See the discussion by Jonathan Jarrett, 'Feudal transformations XV: proving a negative with power relations in Catalonia', A Corner of Tenth-century Europe, 4 Jun 2011, Available from https://tenthmedieval.wordpress.com/2011/06/04/feudal-transformations-xiii-proving-anegative-with-power-relations-in-catalonia/ [Accessed 23 January 2017]. Cf. Bowman, 'Countesses in court' at p. 64.

${ }^{54}$ Bowman, 'Countesses in court' at p. 64.

${ }^{55}$ Ibid. at pp. 64-5; Jonathan Jarrett, Rulers and Ruled in Frontier Catalonia, 880-1010: Pathways of Power (Woodbridge, 2010), pp. 83-5.

${ }^{56}$ R. Hübner, ‘Gerichtsurkunden der fränkischen Zeit. Erste Abteilung: Die Gerichtsurkunden aus Deutschland und Frankreich bis zur Jahre 1000', Zeitschrift der Savigny-Stiftung für Rechtsgeschichte, Germanistische Abteilung 12 (1891), pp. 1-119; Manaresi (ed.), Placiti. Kimberly LoPrete, 'Women, gender and lordship in France, c. 1050-1250', History Compass 5/6 (2007), pp. 1921-41 at p. 1927 states that around 20\% of the counts of Champagne’s feudal tenants in 1050-1250 were women. 
${ }^{57}$ See the six volumes of charters from before 1000 so far published in the series Catalunya carolíngia by Institut d’Estudis Catalans (Barcelona, 1926-).

${ }^{58}$ Ernst Friedrich Johann Dronke, (ed.), Codex diplomaticus Fuldensis (Cassel, 1850) gives texts of around 650 charters from before 900 and around 80 from the tenth century.

${ }^{59}$ Le Jan, Famille et pouvoir, p. 359.

${ }^{60}$ Flavia De Rubeis, 'Epigrafia femminile: la trasformazione delle virtù’, in Christina La Rocca (ed.), Agire da donna: modelli e pratiche di rapprensentazione (secoli VI-X): atti del convegno (Padova, 18-19 febbraio 2005) (Turnhout, 2007), pp. 53-73 at p. 57.

${ }^{61}$ On Bertha see the chapters by Germana Gandino and Tiziana Lazzari in Christina La Rocca (ed.), Agire da donna: modelli e pratiche di rapprensentazione (secoli VI-X): atti del convegno (Padova, 18-19 febbraio 2005) (Turnhout, 2007).

${ }^{62}$ The Carolingian volumes of MGH Epistolae (Berlin, 1892-) contain no letters by comital or ducal women and three letters to them: Alcuin, Epistola 69 to an unnamed duke and his wife (MGH Epp. 4, pp. 112-13); Leo IV, Epistola 21 to Countess Ita (MGH Epp. 5, p. 598) (dubious); Lupus of Ferrières, Epistola 122 to Duke Gerard and his wife Bertha (MGH Epp 6, pp. 102-3). Cf. Flodoard of Rheims, Historia Remensis ecclesiae, ed. Martina Stratmann, MGH SS 36 (Hanover, 1998), 3, 27, pp. 351-2 recording letters by Hincmar of Rheims to two wives of counts (Irmingard and Bertha).

${ }^{63}$ Liudprand of Cremona, Antapodosis, ed. P. Chiesa, Liudprandi Cremonensis opera omnia, CCCM 156 (Turnhout, 1998) I, 39; II, 55 (pp. 27, 57).

${ }^{64}$ Manaresi (ed.), Placiti I, p. 498, no. 133; Luigi Schiaparelli (ed.), I diplomi italiani di Lodovico III e di Rodolfo II (Rome, 1910), pp. 111-13, no. 6.

${ }^{65}$ Liutprand, Antapodosis, III, 7 (p. 71). 
${ }^{66}$ See e.g. Giovanni Drei (ed.), Le Carte degli archivi parmensi dei sec. X-XI (Parma, 1930), pp. 184-6, no. 58 from 953 (Leigarda); Theodor Sickel (ed.), Die Urkunden Otto des III, MGH DD O III (Hanover, 1893), pp. 844-5, no. 411 from 1001 (Ferlinda).

${ }^{67}$ Alois Schmid, 'Herzogin Judith von Bayern', Zeitschrift für Bayerische Landesgeschichte 76 (2013), pp. 389-406 at pp. 393-5.

${ }^{68}$ Le Jan, Famille et pouvoir, pp. 375-6; several letters to Beatrice survive and are translated in Joan Ferrante, Epistolae. Available from

https://epistolae.ccnmtl.columbia.edu/woman/2.html [Accessed 16 February 2017].

Le Jan contrasts Beatrice's role with that of her mother Hedwig, widow of Hugh the Great, who does not seem to have played a prominent role as a widow, despite Hugh Capet being underage.

${ }^{69}$ On Hadwig see Hansmartin Schwarzmaier, ‘Hadwig und Ernst II. Schwäbische Herzogsbilder zwischen Geschichtsforschung, Legende und Dichtung’, Frühmittelalterliche Studien 36 (2002), pp. 285-315 at pp. 285-94; Patricia Tesch-Mertens, 'Hadwig von Schwaben - War die Herzogin eine Frau?’, in Susanne Blumesberger and Ilse Erika Korotin (eds), Frauenbiografieforschung: theoretische Diskurse und methodologische Konzepte (Vienna, 2012), pp. 601-28. On the use of the title 'dux' for women, see Kienast, Herzogstitel, pp. 341-2.

${ }^{70}$ Gerbert of Aurillac, Epistola 50, Die Briefsammlung Gerberts von Reims, ed. Fritz Weigle, MGH Briefe d. dt. Kaizerzeit 2 (Weimar, 1966), pp. 79-80; translated in Joan Ferrante, Epistolae. Available from https://epistolae.ccnmtl.columbia.edu/letter/49.html [Accessed 16 February 2017].

${ }^{71}$ On Adele, see Régine Le Jan, ‘La vengeance d’Adèle ou la construction d’une légende noire’, in Dominique Barthélemy, François Bougard, and Régine Le Jan (eds), La vengeance, 400-1200, Collection de l’École française de Rome, 357 (Rome, 2006), pp. 325-40. 
${ }^{72}$ Jo Ann McNamara and Suzanne Wemple, 'The power of women through the family in medieval Europe: 500-1100’, Feminist Studies 1 (1973), pp. 126-41.

${ }^{73}$ Ibid., p. 137.

${ }^{74}$ Jo Ann McNamara, 'The Herrenfrage: the restructuring of the gender system, 1050-1150', in Clare A. Lees (ed.), Medieval Masculinities: Regarding Men in the Middle Ages (Minneapolis, 1994), pp.3-29 at p. 5; Jo Ann McNamara, 'Canossa and the ungendering of the public man', in Constance Hoffman Berman (ed.), Medieval Religion: New Approaches (New York, 2005), pp.102-22.

${ }^{75}$ See e.g. Pauline Stafford, Queens, Concubines and Dowagers: the King's Wife in the Early Middle Ages, Paperback ed. (London, 1998), pp. xvii-xviii; Amy Livingstone, 'Aristocratic women in the Chartrain', in Theodore Evergates (ed.), Aristocratic Women in Medieval France (Philadelphia, 1999), pp. 44-73 at pp. 71-72; Theresa Earenfight, Queenship in Medieval Europe (Basingstoke, 2013). However Amalie Fössel, 'Gender and rulership in the medieval German empire’, History Compass 7 (2009), pp. 55-65 does see a decline in opportunities for royal women in the Holy Roman Empire.

${ }^{76}$ See e.g. Yves Sassier, 'L’utilisation d'un concept romain aux temps carolingiens. La res publica aux IXe et Xe siècles’, Médiévales, no. 15 (1988), pp. 17-29; Janet L. Nelson, 'The problematic in the private’, Social History 15 (1990), pp. 355-64; Rudolf Schieffer, 'Die internationale Forschung zur Staatlichkeit in der Karolingerzeit’, in Walter Pohl and Veronika Wieser (eds), Der frühmittelalterliche Staat: europäische Perspektiven, Forschungen zur Geschichte des Mittelalters, 16 (Vienna, 2009), pp. 43-9.

${ }^{77}$ Wemple, Women, pp. 194-195.

${ }^{78}$ Santinelli, Femmes éplorées, pp. 369-72 discusses some of the political activities of Merovingian royal widows acting as regents. On Plectrude, the widow of the mayor of the 
palace Pippin II, and her brief and unsuccessful regency for her underage grandson, see Paul Fouracre, The Age of Charles Martel (Harlow, 2000), pp. 58-65.

${ }^{79}$ Le Jan, Famille et pouvoir, pp. 357-65, Le Jan, 'Épouse du comte’.

${ }^{80}$ Le Jan, ‘Épouse du comte’, pp. 65-8.

${ }^{81}$ Le Jan, Famille et pouvoir, pp. 354-5.

${ }^{82}$ Le Jan, ‘Épouse du comte’, p. 70. On this ideology, see Pierre Toubert, ‘La théorie du mariage chez les moralistes carolingiens', Il Matrimonio nella società altomedievale, 22-28 aprile 1976, Settimane, 24 (Spoleto, 1977), I, pp. 233-85; Philip Lyndon Reynolds, Marriage in the Western Church: the Christianisation of Marriage during the Patristic and Early Medieval Periods (Leiden, 1994), pp. 386-419.

${ }^{83}$ See e.g. Pauline Stafford, Queens, Concubines and Dowagers, pp. 127-34; Janet L. Nelson, 'Early medieval rites of queen-making and the shaping of medieval queenship', in Anne Duggan (ed.), Queens and Queenship in Medieval Europe: Proceedings of a Conference held at King's College London, April 1995 (Woodbridge, Suffolk, 1997), pp. 301-15.

${ }^{84}$ Janet L. Nelson, 'Bertrada’, in Matthias Becher and Jörg Jarnut (eds), Der Dynastiewechsel von 751: Vorgeschichte, Legitimationsstrategien und Erinnerung (Münster, 2004), pp. 93108 at p. 101.

${ }^{85}$ Le Jan, Famille et pouvoir, p. 361. On the epithet 'Dei gratia' see Stuart Airlie, 'The political behaviour of the secular magnates in Francia, 829-879', unpublished D.Phil. thesis, University of Oxford (1985), pp. 276-9; Geoffrey Koziol, Begging Pardon and Favor: Ritual and Political Order in Early Medieval France (Ithaca, 1992), pp. 29-30.

${ }^{86}$ Le Jan, ‘Épouse du comte’, pp. 71-2.

${ }^{87}$ Le Jan, Famille et pouvoir, pp. 414-26; Le Jan, ‘Épouse du comte’, p. 71.

${ }^{88}$ See Susan Treggiari, Roman Marriage: iusti coniuges from the Time of Cicero to the Time of Ulpian (Oxford, 1991), pp. 229-61. 
${ }^{89}$ See above, n. 83.

${ }^{90}$ Le Jan, Famille et pouvoir, p. 297.

${ }^{91}$ See e.g. Martin Aurell, 'Jalons pour une enquête sur les strategies matrimoniales des

Comtes catalans (IXe-XIe s.)', Symposium Internacional Sobre els Orígens de Catalunya: (segles VIII-XI) (Barcelona, 1991), I, pp. 281-364.

${ }^{92}$ Karl Schmid, 'Zur problematik von Familie, Sippe und Geschlecht, Haus und Dynastie beim mittelaterlichen Adel. Vorfragen zum thema 'Adel und Herrschaft im Mittelalter’, Zeitschrift für die Geschichte des Oberrheins 105 (1957), pp. 1-62; Georges Duby, 'Lineage, nobility and knighthood. The Mâconnais in the twelfth century - a revision', The chivalrous society (London, 1977), pp. 59-80. On critiques of this paradigm, see Pauline Stafford, 'La mutation familiale: a suitable case for caution', in Joyce Hill and Mary Swan (eds), The Community, the Family and the Saint: Patterns of Power in Early Medieval Europe, International Medieval Research, 4 (Turnhout, 1998), pp. 103-25; Theodore Evergates, 'The feudal imaginary of Georges Duby’, Journal of Medieval and Early Modern Studies 27 (1997), pp. 641-60 at pp. 648-50.

${ }^{93}$ Le Jan, Famille et pouvoir, pp. 423-6.

${ }^{94}$ Ibid., pp. 406-13.

${ }^{95}$ Constance Brittain Bouchard, 'The Carolingian creation of a model of patrilineage', in Celia Chazelle and Felice Lifshitz (eds), Paradigms and Methods in Early Medieval Studies (Basingstoke, 2007), pp. 135-51; Constance Brittain Bouchard, Rewriting Saints and Ancestors: Memory and Forgetting in France, 500-1200 (Philadelphia, 2015), pp. 176-92. ${ }^{96}$ Stasser, 'Maison vicomtale‘, p. 490, citing Pierre de Marca, Marca hispanica, sive, Limes hispanicus: hoc est, geographica \& historica descriptio Cataloniae, Ruscinonis, \& circumjacentium populorum (Paris, 1688), col. 847, no. 72: 'Ego Richildes vicecomitissa filia Borrelli comitis et filia Garsindis comitissa condam.' 
${ }^{97}$ Cited by François Bougard, 'Entre Gandolfingi et Obertenghi: les comtes de Plaisance aux Xe et XIe siècles', Mélanges de l'Ecole française de Rome. Moyen Âge 101, no. 1 (1989), pp. 11-66 at p. 28: 'Lanfrancus comes filius quondam Rinprandi itemque comitis et Berta iugalibus filia bone memorie Adalberti marhio’.

${ }^{98}$ Dhuoda, Liber manualis 3-5, 3-8, pp. 96, 107.

${ }^{99}$ Stone, Morality, pp. 148-52.

${ }^{100}$ Hincmar of Rheims, De ordine palatii, ed. Thomas Gross and Rudolf Schieffer, MGH Font. iur. Germ. 3 (Hanover, 1980) p. 96, c. 37: ‘quoniam de his, quos tempore domni Hludovici imperatoris vidi palatii procuratores et regni praefectos, neminem scio esse superstitem; scio tamen de illorum nobilitate natos pro patribus filios, licet illorum mores ac qualitates ignorem..quatenus merito patrum loca et officia suppleant.’

${ }^{101}$ Claude de Vic and Joseph Vaissète, Histoire générale de Languedoc, avec des notes et les piéces justificatives, (Toulouse, 1872-92), V, col. 323, no. 151: ‘Ad Raymundum vicecomitem, filium meum, dono ipsum vicecomitatum de Narbona seu de Narbonense’. 